\title{
Perfil bioquímico de amostras de Escherichia coli isoladas de materiais avícolas no Estado do Rio Grande do Sul e sua relação com a patogenicidade*
}

\author{
FLÁVIA BORNANCINI BORGES FORTES \\ Carlos Tadeu Pippi Salle (Orientador - UFRGS)
}

Banca: Benito Guimarães de Brito (IPVDF), Sérgio José de Oliveira (ULBRA), Hamilton Luiz de Souza Moraes (UFRGS)

A Escherichia coli é um microorganismo pertencente à flora bacteriana entérica de animais e seres humanos, estando amplamente disseminada na natureza. A colonização intestinal ocorre logo após o nascimento, sendo que 10 a $20 \%$ das E. coli podem ser potencialmente patogênicas para as aves. Essa bactéria representa um problema econômico na indústria avícola, pois é responsável por causar as colibaciloses. Este termo refere-se a qualquer tipo de infecção, localizada ou sistêmica, causadas total ou parcialmente por amostras patogênicas de E. coli. Como exemplos, podem-se citar os problemas respiratórios, como aerosaculite e pneumonias, além de peritonite, onfalite, salpingite e sinovite, entre outros. Além disso, a E. coli é o agente mais freqüentemente isolado nos casos de celulite aviária, provocando lesões cutâneas que levam as carcaças à condenação total ou parcial no momento do abate, provocando relevantes prejuízos. O objetivo deste trabalho foi verificar o perfil bioquímico de 261 amostras de $E$. coli, obtidas a partir de diferentes materiais de origem aviária, coletados no Rio Grande do Sul. Posteriormente, estes resultados foram associados com os Índices de Patogenicidade (IP) de cada amostra, verificando a possibilidade de relacioná-los. Além do teste de hemólise, foram realizadas 21 provas bioquímicas, sendo dez variáveis para E. coli. Dentre os testes variáveis, a melibiose, o sorbitol e a ramnose foram considerados positivos para as bactérias analisadas, pois mais de $90 \%$ das amostras fermentaram esses carboidratos. A salicina, a sacarose, a rafinose, o adonitol e o dulcitol, bem como a arginina e a ornitina continuaram apresentando-se como testes variáveis para E. coli. Os demais testes tiveram resultados positivos ou negativos, de acordo com o esperado para E. coli. Constatou-se que as amostras positivas para arginina, dulcitol, rafinose e sacarose têm maiores Índices de Patogenicidade que as negativas. Por outro lado, as amostras negativas para a salicina e para o teste de indol também possuem IP's mais altos que as positivas. Os resultados dos testes também foram analisados agrupando-se as amostras de acordo com a sua origem (quadros respiratórios, camas de aviários e lesões de celulite), apontando-se diferenças nos IP's ao compará-los entre si.

Descritores: Escherichia coli, patogenicidade, bioquimismo, avicultura, colibacilose, perfil bioquímico.

Apresentada: 29 fevereiro 2008

*Dissertação de Mestrado n. 502 (Especialidade: Sanidade Avícola). 53f. Programa de Pós-graduação em Ciências Veterinárias [www.ufrgs.br/ ppgcv], Faculdade de Veterinária, Universidade Federal do Rio Grande do Sul (UFRGS), Porto Alegre/RS. CORRESPONDÊNCIA: F. B. B. Fortes [flaviafortes@hotmail.com]. 


\title{
Biochemical profile of Escherichia coli samples isolated from avian material at Rio Grande do Sul State and its relation with the pathogenicity**
}

\author{
FLÁVIA BORNANCINI BORGES FORTES
}

\author{
Carlos Tadeu Pippi Salle (Adviser - UFRGS)
}

Committee: Benito Guimarães de Brito (IPVDF), Sérgio José de Oliveira (ULBRA), Hamilton Luiz de Souza Moraes (UFRGS)

The Escherichia coli are microorganisms that belong to the enteric bacterial flora of animals and humans, and are widespread in the nature. The intestinal colonization occurs right after de birth, as 10 to $20 \%$ could be potentially pathogenic to birds. The E. coli represents an economic trouble in the poultry industry, as it's the responsible for causing the colibacilosis. This term refers to any kind of infection, localized or systemic, caused entirely or partly by pathogenic E. coli. As examples, it's possible to quote the respiratory problems, as aerosaculitis and pneumonia, yonder peritonitis, onfalitis, salpingitis and sinovitis, among others symptoms. Besides that, E. coli is the most frequently isolated agent in avian cellulitis cases, promoting cutaneous lesions that brings the carcasses to total or partial condemnation in the abattoir, resulting in relevant prejudices. The objective of the present work was to verify the biochemical profile of $261 \mathrm{E}$. coli samples, obtained from different avian materials, collected in Rio Grande do Sul. Later, these results were associated to the Pathogenic Index (PI) of each sample, to verify if it was possible to relate them. Besides the hemolysis test, 21 biochemical's tests were done, as ten were variable for $E$. coli. Among the variable tests, the melibiose, sorbitol and rhamnose were considered positive for the analyzed samples, as more than $90 \%$ fermented these carbohydrates. The salicin, sucrose, raffinose, adonitol and dulcitol, as arginine and ornithine still variable to $E$. coli. The results of the rest of the tests (positives and negatives) agree with what were expected for $E$. coli. It was noticed that the samples that were positive for arginine, dulcitol, raffinose and sucrose have higher Pathogenic Indexes than the others. On the other hand, the samples that were negative for salicin and indole test also possess high PI's. The results of those tests were also analyzed aggregating the samples according to their origin (respiratory symptoms, avian litter and celullitis lesions), pointing to differences in the PI when comparing to each other.

Key words: Escherichia coli, pathogenicity, biochimism, aviculture, colibacilosis, biochemical profile.

Presented: 29 February 2008

**Master's Thesis \#502 (Field: Avian Sanity). 53p. Graduate Program in Veterinary Sciences [www.ufrgs.br/ppgcv], Faculdade de Veterinária, Universidade Federal do Rio Grande do Sul (UFRGS), Porto Alegre/Brazil. CORRESPONDENCE: F. B. B. Fortes [flaviafortes@hotmail.com]. 